\title{
ANALISIS PENERAPAN SISTEM INFORMASI AKADEMIK (SIAKAD) DALAM UPAYA PENINGKATAN KINERJA PELAYANAN ADMINISTRASI AKADEMIK DI UNIVERSITAS SINGAPERBANGSA KARAWANG
}

\author{
Ani Rahmawati Absi, Puji Isyanto, Eman Sulaeman \\ Program Studi Magister Manajemen, Fakultas Ekonomi dan Bisnis \\ Universitas Singaperbangsa Karawang \\ Email : aniabsi81@gmail.com,puji_isyanto@yahoo.co.id,
}

\begin{abstract}
The aim of research to analyze policies, implementation, performance of academic administrative services, efforts Stakeholders in the supervision of management information systems academic administrative services, and the impact of academic information system (SIAKAD) in an effort to improve the performance of the academic administration at the University Singaperbangsa Karawang.

The thesis is expected to contribute to the bearers of economics in particular; application of academic information system (SIAKAD), Human Resource Management, Information Systems Management, and economics in general. This study uses a qualitative approach to data collection techniques are observation, interviews and in-depth interviews. The results were analyzed by comparing answers interviews with expert informants Judgment and create Conclusions and Recommendations.

From the analysis of research data, be concluded as follows: 1) Policy management Singaperbangsa University Karawang already exists and has been referred to the Higher Education regulations only require better oversight again. 2) University Singaperbangsa Karawang already implementing integrated SIAKAD but still partial. 3) Performance of academic administrative services at the University of Singaperbangsa Karawang good enough after their SIAKAD. 4) Efforts Stakeholders in the supervision of the University Singaperbangsa SIAKAD in Karawang enough and needs to be increased again. 5) The impact of the application of SIAKAD enough to affect the performance of academic administrative services at the University Singaperbangsa Karawang.

Furthermore, the sustainability of recommendation; SOP has been given by the Higher Education dilakuka timely and well as impact on the Quality of Higher Education. Network of SIAKAD needs to be improved. Rules Regulations of Higher Education also greatly affect the performance improvement of the service provider and academic administration. About Integration of reporting systems in each Prodi needs to be implemented immediately. Hopefully, by the Decree of the Rector of the University of Singaperbangsa Karawang to consider remuneration as a reward from the important task.
\end{abstract}

Keywords: Application, Academic Information Systems, Service Performance.

180. Jurnal Manajemen \& Bisnis Kreatif 


\section{Pendahuluan}

Universitas-universitas dalam menghadapi kondisi persaingan global juga telah mulai menerapkan langkah-langkah strategis, terutama dalam hal penggunaan teknologi informasi untuk mendukung proses pendidikannya. Hal ini ditandai dengan telah terbangunnya jaringan intranet kampus dan sistem informasi akadamik (SIAKAD) yang mendukung proses belajar mengajar di lingkungan kampus.

Menurut data DIKTI tahun 2016, perguruan tinggi negeri di Jawa Barat prosentasi Politeknik $10 \%$, Sekolah Tinggi $8 \%$,Universitas dan Akademik $6 \%$ dan Institut $5 \%$. Perbedaan persentase tersebut menunjukkan daya saing dalam penyelenggaraan pendidikan yang terbaik bagi mahasiswa. Disinilah merupakan persaingan untuk menunjukkan keunggulan dari setiap perguruan tinggi di Jawa Barat. Hal ini tentunya ditunjang dengan fasilitas yang dimiliki oleh setiap perguruan tinggi. Salah satu yang memiliki peranan penting adalah pelayanan sistem informasi akademik yang merupakan penentu untuk menarik mahasiswa sebagai konsumen utamanya. Sehingga apabila pelayanan administrasi tidak memperhatikan dimensi kualitas pelayanan, mahasiswa tidak akan merasa puas atas pelayanan administrasi yang diberikan.

Berdasarkan studi pendahuluan yang dilakukan di Badan Penjaminan Mutu Universitas Singaperbangsa Karawang, dengan mewawancarai ketua Badan Penjaminan Mutu Universitas Singaperbangsa Karawang dan mengamati proses pelayanan akademik di Biro Akademik. Universitas Singaperbangsa Karawang sebelumnya adalah perguruan tinggi swasta yang menggunakan sistem informasi akademik yang programnya disebut dengan EPSBED (Evaluasi Program Studi Berbasis Evaluasi Diri) yang harus dilaporkan kepada KOPERTIS. Setelah status Universitas Singaperbangsa Karawang berubah menjadi perguruan tinggi negri ada sedikit perubahan dalam sistem informasi administrasi akademiknya menjadi Feeder DIKTI, karena pelaporan data akademik langsung masuk pada feeder DIKTI.

Menurut hasil observasi awal diperoleh informasi jumlah pegawai administrasi akademik di Universitas Singaperbangsa Karawang sebanyak 9 (sembilan) orang dengan rincian, Kepala Biro Akademik, Kepala Bagian Administrasi Akademik, Kepala Bagian Administrasi Registrasi, Staf Administrasi Akademik sebanyak 4 orang dan Staf Administrasi Registrasi sebanyak 2 orang. Biro Administrasi Akademik merupakan pusat pengolahan dari smua data input yang dikirim dari 23 Program Studi yang ada di Universitas Singaperbangsa Karawang. Sehingga tenaga administrasi atau yang disebut operator dari tiap Program Studi juga memiliki peranan yang besar dalam pemberian data yang tepat untuk diolah di Biro Administras Akademik sebelum dikirimkan kepada Feeder DIKTI.

Hasil kesimpulan dari SWOT yang berhubungan dengan Sistem Informasi Administrasi Akademik adalah web-site yang kurang efektif karena kurang up to date, masih ada informasi lama yang terpampang dan informasi baru agak terlambat. Sistem Informasi Administrasi Akademik sangat perlu didukung oleh Web Site yang optimal.

Peta SWOT tersebut maka dapat dijadikan dasar untuk dilakukan penelitian terhadap Universitas Singaperbangsa Karawang. Salah satu kelemahan 
dari implementasi sarana dan prasarana penunjang Sistem Informasi Administrasi Akademik adalah sarana dan prasarana serta bidang sumber daya manusia. Implementasi Sistem Informasi Administrasi Akademik UNSIKA belum dilakukan secara optimal karena dalam proses peralihan dan penyesuaian dari EPSBED (Evaluasi Program Studi Berbasis Evaluasi Diri) menjadi Feeder DIKTI dimana belum berjalan seluruhnya pada setiap program studinya.

\section{Perumusan Masalah}

Berdasarkan fokus penelitian di atas maka perumusan masalah dalam penelitian adalah : Bagaimana kebijakan manajemen Universitas Singaperbangsa Karawang dalam menangani penerapan sistem informasi pelayanan administrasi akademik, Bagaimana penerapan sistem informasi akademik (SIAKAD) di Universitas Singaperbangsa Karawang upaya untuk meningkatkan kinerja pelayanan administrasi akademik, Bagaimana kinerja pelayanan administrasi akademik di Universitas Singaperbangsa Karawang, Bagaimana upaya Stakeholder dalam pengawasan sistem informasi akademik (SIAKAD) dalam peningkatan pelayanan administrasi akademik di Universitas Singaperbangsa Karawang, Bagaimana dampak penerapan sistem informasi akademik (SIAKAD) dalam upaya meningkatan kinerja pelayanan administrasi akademik di Universitas Singaperbangsa Karawang.

\section{Tinjauan Pustaka}

George R. Terry, (2011 : 2) menyatakan bahwa pengertian manajemen adalah Management is a distinct process consisting of planning, organizing, actuating, and controlling performed to determine and accomplish stated objectives by the use of human being and other resources. Artinya: Manajemen adalah suatu proses yang khas yang terdiri dari tindakan-tindakan perencanaan, pengorganisasian, pengarahan, dan pengendalian yang dilakukan untuk menentukan serta mencapai sasaran-sasaran yang telah ditentukan melalui pemanfaatan sumber daya manusia dan sumber-sumber lainnya.

Manajemen sumber daya manusia (MSDM) merupakan salah satu bidang dari manajemen umum yang meliputi segi-segi perencanaan, pengorganisasian, pelaksanaan dan pengendalian. Proses ini terdapat dalam fungsi/bidang produksi, pemasaran, keuangan, maupun kepegawaian. Sumber daya manusia (SDM) dianggap semakin penting perannya dalam pencapaian tujuan perusahaan, maka berbagai pengalaman dan hasil penelitian dalam bidang SDM dikumpulkan secara sistematis dalam apa yang disebut manajemen sumber daya manusia. Istilah "manajemen" mempunyai arti sebagai kumpulan pengetahuan tentang bagaimana seharusnya memanage (mengelola) sumber daya manusia (menurut Rivai, Veithzal dan Sagala, Ella Jauvani (2011: 1)

SDM adalah rancangan sistem-sistem formal dalam sebuah organisasi untuk memastikan penggunaan bakat manusia secara efektif dan efisien guna mencapai tujuan organisasi. Mathis dan Jackson (2006:3)

Sistem Informasi Manajemen (SIM) menurut Raymond McLeod, Jr (2001 : 327) didefinisikan sebagai suatu sistem berbasis komputer yang menyediakan informasi bagi beberapa pemakai dengan kebutuhan yang serupa. Para pemakai 
biasanya membentuk suatu entitas organisasi formal-perusahaan atau subunit di bawahnya. Informasi menjelaskan perusahaan atau salah satu sistem utamanya mengenai apa yang telah terjadi di masa lalu, apa yang sedang terjadi sekarang dan apa yang mungkin terjadi di masa depan. Informasi tersebut tersedia dalam bentuk laporan periodik, laporan khusus, dan output dari simulasi matematika. Output informasi digunakan oleh manajer maupun non-manajer dalam perusahaan saat mereka membuat keputusan untuk memecahkan masalah.

Kualitas layanan harus dimulai dari kebutuhan pelanggan dan berakhir dengan kepuasan pelanggan serta persepsi serta persepsi positif terhadap kualitas layanan. Sebagai pihak yang membeli dan mengkonsumsi produk/jasa, pelanggan (dan bukan produsen atau penyedia jasa) yang menilai tingkat kualitas layanan sebuah perusahaan. Tantangannya, penilaian konsumen terhadap kinerja layanan yang diterimanya bersifat subyektif, karena tergantung persepsi masing-masing dan personal selling), karenanya sering pula disebut persuasion-based standard atau marketer supplied standard (Spreng, MacKenzie \& Olshavsky, 1996 dalam Tjiptono, Fandy $2012: 160$ ).

Menurut WH Evans dalam Badri Munir Sukoco(2007 : 3) definisi administrasi perkantoran adalah fungsi yang menyangkut manajemen dan pengarahan semua tahap operasi perusahan mengenai pengolahan bahan keterangan, komunikasi, dan ingatan organisasi.

Sistem Informasi Akademik (SIAKAD) secara khusus dirancang untuk memenuhi kebutuhan Perguruan Tinggi yang menginginkan layanan pendidikan yang terkomputerisasi untuk meningkatkan kinerja, kualitas pelayanan, daya saing dan kualitas SDM yang dihasilkannya. Sistem Informasi Akademik (SIAKAD) sangat membantu dalam pengelolaan data nilai mahasiswa, mata kuliah, data staf pengajar (dosen) serta administrasi fakultas/jurusan yang sifatnya masih manual untuk dikerjakan dengan bantuan Software agar mampu mengefektifkan waktu dan menekan biaya operasional. Sistem Informasi Akademik juga telah disesuaikan dengan kebutuhan Perguruan Tinggi termasuk pembuatan laporan EPSBED (Evaluasi Program Studi Berbasiskan Evaluasi Diri) yang diserahkan kepada DIKTI setiap semester secara otomatis (menurutt Mcleod.Jr, Raymond (2001 : 546).

\section{Metode Penelitian}

Penelitian ini menggunakan Pendekatan Kualitatif dengan teknik pengumpulan data secara observasi, wawancara dan wawancara mendalam. Hasil wawancara dianalisis dengan membandingkan jawaban informan dengan expert Judgment serta membuat Simpulan dan Saran. Informan diperoleh dari Pendapat dari Rektor UNSIKA, Ka Biro Administrasi Akademik, Ketua BPM, Ka Prodi, dan Operator akan dibandingkan dengan pendapat Dikti, dan mahasiswa sebagai pengguna pelayanan SIAKAD. 


\section{Hasil Penelitian}

Berdasarkan hasil wawancara yang dilakukan kepada 3 Pimpinan pada unit Rektorat (1 orang Rektor UNSIKA, 1 orang Ka. Biro Administrasi Akademik dan 1 orang Ketua Badan Penjaminan Mutu), 2 staf administrasi akademik (1 orang staf yang sudah berada di PUSDATIN UNSIKA), $21 \mathrm{Ka}$ Prodi diambil 1 orang Ka. Prodi, 1 staf administrasi regristasi dan 2 orang operator administrasi akademik, dari 20 Program Studi diambil 1 orang mahasiswa dari setiap Prodi. Sebagai Expert Judgmentnya dilakukan wawancara dengan pihak DIKTI Jakarta yang diwakilkan oleh Kassubbid Pusdatin Dikti Jakarta.

Berdasarkan studi pendahuluan diperoleh informasi masih ada program studi yang belum online SIAKADnya, dan ada beberapa yang sarana komputernya rusak informasi diperoleh dari mahasiswi S1 Ilmu Hukum. Tetapi lebih dari 50\% SIAKAD nya online namun belum maksimal penggunaanya. (Hasil dari wawancara dengan mahasiswa tiap prodi).

Berdasarkan hasil wawancara dan observasi dilapangan bahwa kebijakan tentang SIAKAD di UNSIKA sebagian besar telah mengetahui adanya kebijakan tersebut, hanya mahasiswa yang belum mengetahui tentang kebijakan SIAKAD.

Berdasarkan hasil wawancara dan observasi dilapangan bahwa penerapan sistem informasi akademik di UNSIKA sebagian besar telah mengetahui adanya penerapan tersebut namun tidak tahu tahun pasti dimulainya SIAKAD. Tidak ada dokumen yang dapat menunjukkan awal diterapkannya Sistem Informasi di UNSIKA

Berdasarkan hasil wawancara dan observasi dilapangan bahwa hal yang mempengaruhi penerapan sistem informasi akademik di UNSIKA sebagian besar telah mengetahui adanya hal yang mempengaruhi penerapan SIAKAD yaitu informasi yang terintegrasi atau desentralisasi informasi akademik.

Berdasarkan hasil wawancara dan observasi dilapangan bahwa faktor penghambat sistem informasi akademik di UNSIKA sebagian besar telah mengetahui adanya faktor penghambat tersebut yaitu SDM, sistem jaringan, dan pembiayaan.

Berdasarkan hasil wawancara dan observasi dilapangan bahwa Faktor Pendukung penerapan SIAKAD di UNSIKA sebagian besar telah mengetahui yaitu Kebijakan DIKTI, Kebijakan Pimpinan, SDM, Jaringan dan pembiayaan.

Berdasarkan hasil wawancara dan observasi dilapangan bahwa Kinerja pelayanan operator SIAKAD di UNSIKA sebagian menjawab Cukup baik karena baru dilakuakan online pada SIAKAD di Prodi/fakultasnya, dan juga ada yang menjawab baik terutama pada mahasiswa yang fakultas/prodinya telah ada SIAKAD on line.

Berdasarkan hasil wawancara dan observasi dilapangan bahwa Kinerja pelayanan operator SIAKAD di UNSIKA sebagian besar cukup baik dalam menangani komplen dari mahasiswa, tetapi diharapkan tetap melakukan pelayanan yang ramah dan pendekatan yang baik dengan mahasiswa.

Berdasarkan hasil wawancara dan observasi dilapangan bahwa Kinerja pelayanan operator SIAKAD di UNSIKA sebagian besar cukup baik dan perlu ditingkatkan dalam menangani komplen dari mahasiswa, tetapi diharapkan te tap melakukan pelayanan yang ramah dan pendekatan yang baik dengan mahasiswa. 
Berdasarkan hasil wawancara dan observasi di lapangan bahwa Upaya Stakeholder \& Pengawasan dalam peningkatan Kinerja pelayanan operator SIAKAD di UNSIKA hasilnya adalah pelatihan baik dari UNSIKA dan dari DIKTI Jakarta serta perlunya peningkatan skill atau keterampilan yang berkaitan dengan IT dan komputer .

Menurut hasil dari wawancara yang digambarkan pada diagram fish bone hasilnya adalah dampak dari penerapan SIAKAD sangat mempengaruhi pelaporan yang tepat waktu dan akan meningkatkan kinerja pelayanan administrasi akademik, karena tidak dikejar oleh pelaporan ke PDDIKTI.

\section{Pembahasan}

Kebijakan adalah hal yang sangat penting dalam keberlangsungan suatu organisasi, karena kebijakan merupakan aturan yang memberikan kejelasan dalam suatu tanggung jawab pekerjaan.

Hasil dari penelitian tentang kebijakan diperoleh hampir seluruh informan penelitian sampai pelaksana dan operator SIAKAD di UNSIKA telah mengetahui Kebijakan tentang SIAKAD, kecuali mahasiswa sebagai pengguna SIAKAD.

Hasil pengamatan dan hasil wawancara dengan para informan dan diukur melalui matrik penilaian menghasilkan temuan bahwa Dokumen dari kebijakan ada, namun informasi yang diberikan kurang dapat menjelaskan secara rinci, maka kebijakan manajemen Universitas Singaperbangsa Karawang dalam menangani penerapan sistem informasi pelayanan administrasi akademik dinilai baik.

Kebijakan tersebut hanya mengikat tentang pelaksanaan dan tanggung jawab dalam pelaporan. Belum tampak diterapkannya sanksi apabila terjadi keterlambatan pelaporan. Padahal ketepatan pelaporan sangat penting untuk kelancaran pelaporan dan dapat menunjukkan mutu dari perguruan tinggi.

Pengembangan Organisasi adalah proses perubahan sistematis dan terencana yang menggunakan pengetahuan dan teknik ilmu perilaku untuk memperbaiki kesehatan dan keefektifan suatu organisasi melalui kemampuannya.

Tabel 1

Pendekatan Pengembangan Organisasi terhadap perubahan Budaya

\begin{tabular}{|l|l|l|}
\hline & \multicolumn{1}{|c|}{$\begin{array}{c}\text { Model Pengembangan } \\
\text { Organisasi Tradisional }\end{array}$} & Model Intervensi Kelompok Besar \\
\hline Fokus Tindakan & $\begin{array}{l}\text { Permasalahan tertentu atau } \\
\text { kelompok tertentu }\end{array}$ & Keseluruhan sistem \\
\hline Informasi & Organisasi & Organisasi dan lingkungan \\
\hline Sumber & Terbatas & Disebarkan secara luas \\
\hline Distribusi & Bertahap & Cepat \\
\hline Kerangka Waktu & Individu, Kelompok Kecil & Keseluruhan Organisasi \\
\hline Pembelajaran & Perubahan Inkremental & Transformasi Cepat \\
\hline Proses Perubahan & \multicolumn{2}{|l}{} \\
\hline
\end{tabular}

Sumber : Teori Richard L 
Melalui kebijakan yang baik tentunya merupakan kontrol yang baik sehingga dapat mengatur hubungan dan peranan pelaksana dan operator SIAKAD sehingga lebih efektif dan efisien, sehingga sesuai dengan visi dari Universitas Singaperbangsa Karawang yaitu "Menjadi Perguruan Tinggi yang berdaya saing ditingkat nasional tahun 2020" serta misinya yaitu : Menyiapkan Sumber daya manusia yang ahli dan berakhlak mulia dan Menciptakan, menerapkan dan mengembangkan IPTEKS yang berdaya guna dan berhasil guna.

Hasil pengamatan dan hasil wawancara dengan para informan dan diukur melalui matrik penilaian menghasilkan beberapa temuan.

Sistem Informasi di Universitas Singaperbangsa Karawang berdasarkan hasil wawancara dan observasi dilapangan bahwa penerapan sistem informasi akademik di UNSIKA sebagian besar telah mengetahui adanya penerapan tersebut namun tidak tahu tahun pasti dimulainya SIAKAD. Tidak ada dokumen yang dapat menunjukkan awal diterapkannya Sistem Informasi di UNSIKA. Namun Sistem informasi telah diterapkan di UNSIKA.

Selanjutnya hasil wawancara dan observasi dilapangan bahwa hal yang mempengaruhi penerapan sistem informasi akademik di UNSIKA sebagian besar telah mengetahui adanya hal yang mempengaruhi penerapan SIAKAD yaitu informasi yang terintegrasi atau desentralisasi informasi akademik. Diharapkan dengan terintegrasinya data pada Universitas maka dapat memberikan data secara utuh dan tidak ada prodi atau fakultas yang menonjol di dalam suatu universitas, tetapi yang menonjol adalah universitas tersebut secara utuh.

Selanjutnya hasil wawancara dan observasi dilapangan bahwa faktor penghambat sistem informasi akademik di UNSIKA sebagian besar telah mengetahui adanya faktor penghambat tersebut yaitu SDM, sistem jaringan, dan pembiayaan.

Selanjutnya hasil wawancara dan observasi dilapangan bahwa Faktor Pendukung penerapan SIAKAD di UNSIKA sebagian besar telah mengetahui yaitu Kebijakan DIKTI, Kebijakan Pimpinan, SDM, Jaringan dan pembiayaan.

Sistem Informasi Akademik (SIAKAD) merupakan sebuah aplikasi yang mengintegrasikan seluruh proses inti sebuah bisnis pendidikan ke dalam sebuah sistem informasi yang didukung oleh teknologi terkini. Dengan penerapan SIAKAD akan mempengaruhi mutu layanan secara keseluruhan, yaitu layanan yang berhubungan dengan pihak-pihak di luar lembaga pendidikan (Front Office) dan satu lagi tentunya layanan yang berhubungan dengan internal lembaga pendidikan itu sendiri (Back Office).

Hasil pengamatan dan hasil wawancara dengan para informan dan diukur melalui matrik penilaian menghasilkan beberapa temuan.

Kinerja pelayanan operator SIAKAD di UNSIKA sebagian menjawab cukup baik karena baru dilakukan online pada SIAKAD di Prodi/fakultasnya, dan juga ada yang menjawab baik terutama pada mahasiswa yang fakultas/prodinya telah ada SIAKAD on line.

Temuan selanjutnya bahwa Kinerja pelayanan operator SIAKAD di UNSIKA sebagian besar cukup baik dalam menangani komplen dari mahasiswa, tetapi diharapkan tetap melakukan pelayanan yang ramah dan pendekatan yang baik dengan mahasiswa.

Kinerja (Performance) adalah hasil pekerjaan yang dicapai seseorang berdasarkan persyaratan-persyaratan pekerjaan (job requirement). Suatu pekerjaan 
mempunyai persyaratan tertentu untuk dapat dilakukan dalam mencapai tujuan yang disebut juga sebagai standar pekerjaan (Job standard)

Dengan memaksimalkan kinerja dari setiap operator administrasi akademik dan didukung sistem informasi administrasi akademik yang lebih canggih akan saling menunjang, sehingga mutu perguruan tinggi akan lebih baik lagi.

Penentuan ukuran dari hasil penelitian, peneliti membuat suatu matrik penelitian dengan batasannya dan ditabulasikan sebagai berikut :

Hasil pengamatan dan hasil wawancara dengan para informan dan diukur melalui matrik penilaian menghasilkan bahwa Upaya Stakeholder \& Pengawasan dalam peningkatan Kinerja pelayanan operator SIAKAD di UNSIKA hasilnya adalah pelatihan baik dari UNSIKA dan dari DIKTI Jakarta serta perlunya peningkatan skill atau keterampilan yang berkaitan dengan IT dan komputer.

Dampak penerapan sistem informasi akademik (SIAKAD) dalam upaya meningkatan kinerja pelayanan administrasi akademik di Universitas Singaperbangsa Karawang.

Penentuan ukuran dari hasil penelitian, peneliti membuat suatu matrik penelitian dengan batasannya dan ditabulasikan sebagai berikut :

Hasil pengamatan dan hasil wawancara dengan para informan dan diukur melalui matrik penilaian menghasilkan temuan bahwa dampak dari penerapan SIAKAD masuk kategori cukup dan sangat mempengaruhi pelaporan yang tepat waktu dan akan meningkatkan kinerja pelayanan administrasi akademik, karena tidak dikejar oleh pelaporan ke PDDIKTI.

Sistem Informasi Akademik secara khusus dirancang untuk memenuhi kebutuhan Perguruan Tinggi yang menginginkan layanan pendidikan yang terkomputerisasi untuk meningkatkan kinerja, kualitas pelayanan, daya saing dan kualitas SDM yang dihasilkannya.

Pembahasan terhadap penerapan SIAKAD di Universitas Singaperbangsa Karawang, keterkaitan data hasill penelitian dengan proposisi adalah sebagai berikut :

Kinerja pelayanan administrasi meningkat didukung dengan penerapan sistem yang baik, serta manajemen perubaham yang aktif. Sehingga dapat mencapai visi dan misi dari suatu organisasi. Apabila sistem informasi akademik SIAKAD di UNSIKA ini lebih terintegrasi tentunya akan mempermudah dan dapat mempengaruhi peningkatan kinerja opertor administrasi akademik sehingga Visi UNSIKA yakni "Menjadi Perguruan Tinggi yang berdaya saing ditingkat nasional tahun 2020", akan dapat dicapai seiring dengan upaya yang dilakukan oleh manajemen perubahan dan didukung oleh semua sumber daya manusia.

\section{Simpulan}

Berdasarkan hasil penelitian dan keterkaitan maka kesimpulan yang diperoleh sebagai berikut :

1. Kebijakan manajemen Universitas Singaperbangsa Karawang dalam menangani masalah sistem jaringan dalam penerapan sistem informasi pelayanan administrasi akademik. Kebijakan tersebut dijabarkan melalui SK dari Rektor UNSIKA sebagai Pimpinan Perguruan Tinggi untuk pelaksana dan Operator SIAKAD dimana terdapat tugas dan tanggung jawab dari operator input data pelaporan PDPT DIKTI. Sehingga hal tersebut menunjukkan 
kebijakan manajemen Universitas Singaperbangsa Karawang telah memberikan kebijakan yang baik sesuai ketentuan.

2. Universitas Singaperbangsa Karawang sudah menerapkan Sistem Informasi Akademik (SIAKAD) baik namun saat ini masih belum terintegrasi secara total pada setiap Fakultas dan Prodinya, SIAKAD yang baik adalah SIAKAD yang terintegrasi dengan baik sehingga Perguruan Tinggi dapat menghasilkan pelaporan data yang valid dan tidak terjadi perbedaan SIAKAD diantara fakultas dan Prodinya .

3. Kinerja pelayanan administrasi akademik di Universitas Singaperbangsa Karawang sudah cukup, ditinjau dari hasil wawancara mahasiswa sebagai pengguna dan pihak yang memanfaatkan pelayanan operator administrasi akademik. Perbedaan pelayanan saat sebelum dan sesudah adanya SIAKAD online di UNSIKA dapat dirasakan oleh mahasiswa, dengan adanya SIAKAD online yang terbaru pelayanan operator administrasi akademik cukup baik dibandingkan sebelum SIAKAD yang online diberlakukan. Menurut DIKTI bahwa kinerja operator SIAKAD juga sangat dipengaruhi oleh adanya manajemen perubahan yang baik.

4. Upaya Stakeholder sebagai pengawas adalah dengan mengadakan pelatihan langsung kepada para operator SIAKAD on line sehingga akan meningkatkan kinerja operator SIAKAD, dan dampaknya adalah kepuasan dari pengguna pelayanan SIAKAD online. Stakeholder sebagai pengguna dan pengawas sistem informasi akademik (SIAKAD) tingkat kepuasannya lebih baik dari pada sebelum ada pelayanan on line administrasi akademik di Universitas Singaperbangsa Karawang.

5. Dampak Penerapan SIAKAD yang baik sangat mempengaruhi dalam upaya meningkatan kinerja administrasi akademik di Universitas Singaperbangsa Karawang. SIAKAD diciptakan untuk mempermudah dari pelaksana dan penggunanya, hal ini juga ditunjang pula oleh skill atau kemampuan dari SDM operator SIAKAD untuk mengoperasikan SIAKAD dengan tepat, oleh karena itu dengan terintegrasinya SIAKAD pada setiap Fakultas dan Prodi dapat mempermudah dalam penginputan data pelaporan dan menghasilkan data pelaporan yang lebih valid, sehingga akan berdampak pula pada peningkatan kinerja pelayanan operator SIAKAD.

\section{Daftar Rujukan}

Amir, M.Taufiq.2012. Manajemen Strategik Konsep dan Aplikasi. Jakarta. Rajagrafindo Persada.

Bangun, Wilson. 2012. Manajemen Sumber Daya Manusia.Penerbit Erlangga. Jakarta.

Cooper, Donald R dan Emory, C.William.1995. Metode Penelitian Bisnis.Gelora Aksara Pratama

Cravens, David W. 2000.Strategic Marketing. New York. Penerbit McGraw-Hill Irwin. 
David, Freed.R. 2005. Strategic Management Manajemen strategis.Jakarta. Penerbit Salemba Empat.

Ivancevich, John M., Konopaske, Robert., Matterson, and Michael T. 2005. Perilaku dan Manajemen Organisasi jilid 1. Penerbit PT.Erlangga.

Jogiyanto. 2005. Sistem Teknologi Informasi:Pendekatan Terintegrasi, Konsep:Dasar,Teknologi,Aplikasi, Pengembangan dan Pengelolaan.Yogyakarta.Penerbit ANDI.

Laudon, Kenneth C and Laudon, Jane P.2012. Sistem Informasi Manajemen Mengelola Perusahaan Digital Buku 1 Edisi 10.Jakarta. Penerbit Salemba Empat.

McLeod Jr, Raymond. 2001 Sistem Informasi Manajemen edisi Ketujuh jilid 2.Jakarta. PT Prenhallindo.

McLeod, Raymond dan P Schell, George. 2007. Sistem Informasi Manajemen Edisi kesembilan. PT Indeks, Jakarta

McLeod, Raymond dan P Schell, George. 2007. Management Information Systems tenth edition.New Jersey. Pearson International Edition.

Moleong, Lexy J. 2014. Metodologi Penelitian Kualitatif. Edisi Revisi. Bandung. Penerbit PT. Remaja Rosdakarya

Noe, Hollenbeck, Gerhart,Wright. 2006. Human Resource Management.New York. Penerbit McGraw-Hill Irwin. 